\title{
PENGARUH TINGKAT FUNGI MIKORIZA ARBUSKULA TERHADAP PRODUKTIVITAS RUMPUT GAJAH MINI (Pennisetum purpureum schamach ) PADA TANAH ULTISOL
}

\author{
(Effect of Levels Mycorhiza arbuskular on Productivity of Mini Elephant Grass \\ (Pennisetum purpureum schamach) on the Ultisol)
}

\author{
Reza Prabudi ${ }^{1}$, Nevy Diana Hanafi ${ }^{2}$, Ma'ruf Tafsin ${ }^{2}$ \\ 1. Mahasiswa Program Studi Peternakan Fakultas Pertanian Universitas Sumatera Utara \\ 2. Staff Pengajar Program Studi Peternakan Fakultas Pertanian Universitas Sumatera Utara
}

\begin{abstract}
Availability of feed especially forage is still a difficult problem to overcome, especially in the dry season. Land for forage is also on the wane because displaced by the common uses of residential land and food crops. This led to the use of less fertile land such as soil ultisol should be improved for forage planting medium. This study aimed to examined the growth of Mini Elephant Grass (Pennisetum purpureum schamach) on the ultisol by utilizing different levels of Mycorrhiza arbuscular (FMA). The experiment was conducted at the Agricultural Faculty, Universitas Sumatera Utara started on October 2012 to February 2013. The design used in the study was completely randomized design (CRD). Treatments consists of level mycorrhiza arbuscular $P 0=0 \mathrm{~g}$ FMA/polybag (control), $P 1=10 \mathrm{~g} \mathrm{FMA/polybag,} P 2=20 \mathrm{~g} F M A /$ polybag and $P 3=30 \mathrm{~g} F M A /$ polybag. The variable were studied were plant height, number of tillers, dry matter production, and root biomass of Mini Elephant Grass (Pennisetum purpureum scamach). The results obtained at P0;P1;P2 and P3 on the plant height at cutting I (58,20; 53,20; 63,00 and 54,60 respectively), cutting II (80,40; 61,60; 81,60 and 103,20 respectively), cutting III (127,40; 105,60; 116,20 and 135,00 respectively). The results of cutting the number of tillers in I (1,80;3,40;4,00 and 5,80 respectively), cutting II $(4,80 ; 5,60 ; 10,40$ and 10,40 respectively) and the cutting $I I I(6,80 ; 7,80 ; 12,60$ and 12,60 respectively) and dry matter yield in cutting I (25,75; 30,32; 27,76 and 20,66 respectively), cutting II (24,20; 24,11; 23,99 and 25,80 respectively), cutting III (18,55; 17,30;25,22 and 20,91 respectively). The results showed that root biomass at P0; P1; $P 2$ and P3 (46,95; 54,45; 53,78 and 111,33 respectively). The conclusion was level mycorrhiza arbuscular in treatment P3 (level $30 \mathrm{~g} /$ polybag) showed the best results in productivity mini elephant grass ( Pennisetum purpureum schamach). While the treatment $\mathrm{PO}$ ( control) showed the worst results in productivity mini elephant grass ( Pennisetum purpureum schamach) during the study.
\end{abstract}

Keywords : Mini Elephant Grass, Mycorrhiza arbuscular(FMA), ultisol, grass productivity

\begin{abstract}
ABSTRAK
Ketersediaan pakan ternak, khususnya hijauan masih merupakan masalah yang sulit diatasi terutama pada musim kemarau. Lahan untuk hijauan pakan ternak juga semakin berkurang karena tergeser oleh penggunanan lahan pemukiman dan tanaman pangan. Hal ini menyebabkan pemanfaatan lahan-lahan kurang subur seperti tanah ultisol harus ditingkatkan untuk media tanam hijauan pakan ternak. Penelitian ini bertujuan untuk melihat pertumbuhan rumput gajah mini pada tanah ultisol dengan pemberian berbagai tingkat Fungi Mikoriza Arbuskula (FMA). Penelitian dilaksanakan di Lahan Pertanian Fakultas Pertanian Universitas Sumatera Utara pada bulan Juni sampai dengan Oktober 2012. Rancangan yang dipakai dalam penelitian adalah Rancangan Acak Lengkap (RAL). Perlakuan level mikoriza arbuskula terdiri dari P0 $=0 \mathrm{~g}$ FMA/polybag (kontrol), $\mathrm{P} 1=10 \mathrm{~g}$ FMA/polybag, $\mathrm{P} 2=20$ g FMA/polybag dan P3 = 30 g FMA/polybag. Parameter yang diteliti adalah tinggi tanaman, jumlah anakan, produksi bahan kering, dan biomasa akar rumput Gajah Mini (Pennisetum purpureum Schamach). Hasil penelitian yang diperoleh pada P0; P1; P2 dan P3 terhadap tinggi tanaman pada pemotongan I (58,20; 53,20; 63,00 dan 54,60), pemotongan II $(80,40 ; 61,60 ; 81,60$ dan 103,20), pemotongan III $(127,40 ; 105,60 ; 116,20$ dan 135,00). Hasil jumlah anakan pada pemotongan I $(1,80 ; 3,40 ; 4,00$ dan 5,80), pemotongan II $(4,80 ; 5,60 ; 10,40$ dan 10,40) dan pada pemotongan III $(6,80 ; 7,80 ; 12,60$ dan 12,60$)$ dan hasil produksi bahan kering pada pemotongan I $(25,75 ; 30,32$;
\end{abstract}


27,76 dan 20,66), pemotongan II (24,20; 24,11; 23,99 dan 25,80), pemotongan III (18,55; 17,30; 25,22 dan 20,91). Hasil biomassa akar menunjukkan bahwa pada P0; P1; P2 dan P3 (46,95; 54,45; 53,78 dan 111,33). Kesimpulannya adalah pemberian dosis Mikoriza arbuskula pada perlakuan P3 (level $30 \mathrm{~g} /$ polybag) menunjukkan hasil yang paling baik pada produktivitas rumput gajah mini. Sementara itu perlakuan P0 (kontrol) menunjukkan hasil yang paling buruk pada produktivitas rumput gajah mini selama penelitian.

Kata kunci: Rumput gajah mini, Mycorrhiza arbuscular (FMA), ultisol, produktifitas rumput

\section{PENDAHULUAN}

Penyediaan tanaman pakan ternak memiliki peranan penting dalam perkembangan ruminansia baik dari segi kualitas maupun kuantitasnya. Ternak ruminansia lebih banyak mengkonsumsi pakan hijauan dari seluruh pakan yang dikonsumsinya. Permasalahan yang timbul dalam upaya penyediaan pakan hijauan yang berkualitas baik maupun kuantitas yang cukup dan tersedia sepanjang tahun yaitu rendahnya produktifitas lahan yang digunakan.

Meningkatnya jumlah penduduk khususnya di Indonesia, menyebabkan peningkatan permintaan terhadap hasil ternak. Dengan demikian, upaya untuk meningkatkan produktivitas perlu dilakukan pemenuhan kebutuhan manusia akan protein hewani seperti daging, telur dan susu. Peternakan ruminansia seperti sapi, kambing, domba dan kerbau membutuhkan hijauan sebagai makanan tenak, baik berupa rumput-rumputan maupun leguminosa (Rismunandar, 1986).

Upaya peningkatan volume produksi peternakan memerlukan perbaikan proses produksi dan kualitas bahan pakan. Salah satu faktor yang menentukan perkembangan ternak ruminansia adalah pakan. Pakan utama ternak ruminansia terdiri dari rumput dan leguminosa. Leguminosa adalah jenis tumbuhan yang termasuk keluarga polong-polongan atau kacang-kacangan.

Ketersediaan pakan ternak, khususnya hijauan masih merupakan masalah yang sulit diatasi terutama pada musim kemarau. Lahan untuk hijauan pakan ternak juga semakin berkurang karena tergeser oleh penggunanan lahan pemukiman dan tanaman pangan. Hal ini menyebabkan pemanfaatan lahan-lahan kurang subur seperti tanah ultisol harus ditingkatkan untuk media tanam hijauan pakan ternak (Reksohadiprodjo, 1985) .

Tanah Ultisol sering diidentikkan dengan tanah yang tidak subur dan memiliki tingkat kemasaman yang cukup tinggi ( $\mathrm{pH} 5,5$ ), tetapi sesungguhnya bisa dimanfaatkan untuk lahan pertanian potensial, asalkan dilakukan pengelolaan yang memperhatikan kendala tersebut, 
misalnya dengan pemupukan dan penambahan bahan-bahan organik, misalnya Mikoriza arbuskula.

Keuntungan yang diharapkan dari penggunaan mikoriza ini kaitannya dengan pertumbuhan, kualitas dan produktivitas tanaman hijauan. Fungi Mikoriza arbuskula (FMA) dapat membantu akar tanaman dalam penyerapan unsur hara makro dan mikro terutama fosfat, meningkatkan penyerapan air oleh tanaman dan meningkatkan ketahanan tanaman terhadap cekaman kekeringan. Fungi ini juga menghasilkan zat pengatur tunmbuh (hormon) yang dapat menstimulasi pertumbuhan tanaman.

Diharapkan dengan adanya penelitian ini, produksi Hijauan Makanan Ternak (HMT) dapat meningkat, sehingga kebutuhan pakan ternak khususnya ruminansia dapat terpenuhi secara maksimal. Tanah ultisol yang merupakan tanah marginal pun akan lebih baik kualitasnya dengan penggunaan Mikoriza Arbuskula. Hal ini disebabkan karena Mikoriza arbuskula dapat membantu penyerapan hara oleh tanaman dan menstimulasi pertumbuhan tanaman serta dapat memperbaiki sifat tanah ultisol tersebut

\section{BAHAN DAN METODE PENELITIAN}

\section{Tempat dan Waktu Penelitian}

Penelitian ini dilaksanakan di lahan percobaan Fakultas Pertanian Universitas Sumatera Utara pada bulan Oktober 2012 sampai bulan Februari 2013.

\section{Bahan dan Alat Penelitian}

\section{Bahan}

Bahan yang digunakan dalam penelitian ini adalah rumput gajah mini (Pennisetum purpureum schamach). Rumput ini diperoleh dari Laboratorium Sei Putih, Fungi Mikoriza Arbuskula (FMA) yang diperoleh dari Laboratorium Institut Pertanian Bogor (IPB) dan tanah ultisol yang diperoleh dari Desa Kuala Bekala Kelurahan Simalingkar Kecamatan Pancur Batu deli serdang.

\section{Alat}

Alat yang digunakan antara lain : polybag plastik ukuran $5 \mathrm{~kg}$ sebagai wadah tanah untuk menanan hijauan, timbangan sebagai alat untuk menimbang berat tanah yang akan dimaukkanke dalam polybag, meteran sebagai alat untuk menghitung tinggi tanaman, ayakan tanah sebagai 
alat untuk memisahkan tekstur tanah yang kasar dan yang halus, gunting sebagai alat untuk memotong hijauan pada saat trimming, pisau sebagai alat untuk memotong hijauan pada saat penanaman dan masa panen serta oven sebagai alat untuk mengoven hijauan pada saat trimming dan panen.

\section{Metode Penelitian}

Penelitian ini menggunakan rancangan acak lengkap dengan empat perlakuan dan lima ulangan, perlakuan yang diberikan yaitu perbedaan dosis mikoriza. Perlakuan tersebut adalah sebagai berikut:

$\mathrm{P}_{0}=0$ gram CMA (kontrol)/polybag

$\mathrm{P}_{1}=10$ gram CMA /polybag

$\mathrm{P}_{2}=20$ gram CMA/polybag

$\mathrm{P}_{3}=30$ gram CMA/polybag.

Penelitian ini terdiri atas 20 satuan percobaan. Penelitian ini dilakukan di lahan dengan menggunakan polybag. Dalam 1 polybag digunakan $5 \mathrm{~kg}$ tanah. Model linear yang akan digunakan adalah Rancangan Acak Lengkap (RAL) dengan model rancangan sebagai berikut:

$$
\mathrm{Yij}=\mu+\mathrm{Ti}+- \text { : }
$$

Keterangan:

Yij : data yang disebabkan

pengaruh perlakuan pada taraf

ke-i dan ulangan ke-j

$\mu \quad$ : rataan atau nilai tengah

$\mathrm{Ti}$ : efek dari perlakuan pada taraf

ke-i

: efek error dari perlakuan ke-i

dan ulangan ke-j

\section{Parameter Penelitian}

\section{Pertumbuhan Tinggi Vertikal Tanaman (cm)}

Tinggi tanaman diukur dari permukaan tanah sampai ujung daun tertinggi dengan cara mengatupkan seluruh daun keatas dengan tangan sampai tegak lurus kemudian dilakukan 
pengukuran secara vertikal pada bagian tanaman yang paling tinggi dari permukaan tanah. Tanah tanaman diukur setiap 1 minggu sekali (Aryanto dan Polakitan, 2009).

\section{Jumlah Anakan (rumpun)}

Anakan rumput yang dihitung adalah anakan yang muncul dari dalam tanah atau tumbuh pada rhizoma batang sesuai perlakuan. Jumlah anakan diukur setiap satu minggu sekali (Aryanto dan Polakitan, 2009).

\section{Produksi Bahan Kering (g)}

Produksi bahan kering diperoleh dari produksi bahan segar dari setiap pemotongan umur 4 minggu, setelah pemotongan dilakukan penimbangan tiap petak percobaan. Dari penimbangan tersebut akan didapatkan data dari produksi segar. Kemudian sampel dioven untuk mendapatkan bobot kering (Aryanto dan Polakitan, 2009).

\section{Biomassa Akar (g)}

Biomassa adalah jumlah bahan organik yang diproduksi oleh organisme (tumbuhan) per satuan unit area pada suatu saat. Biomassa bisa dinyatakan dalam ukuran berat, seperti berat kering dalam satuan gram, atau dalam kalori. Oleh karena kandungan air yang berbeda setiap tumbuhan, maka biomassa di ukur berdasarkan berat kering. Unit satuan biomassa adalah g per $\mathrm{m}^{2}$ atau ton per ha (Aryanto dan Polakitan, 2009).

\section{HASIL DAN PEMBAHASAN}

Hasil penelitian pemberian fungi Mikoriza arbuskular terhadap produktivitas rumput gajah mini (Pennisetum purpureum schamach) pada semua parameter yaitu tinggi tanaman, jumlah anakan, produksi bahan kering dan biomassa akar tersaji pada Tabel 1.

\section{Tinggi Tanaman (cm)}

Tinggi tanaman diukur dari permukaan tanah sampai ujung daun tertinggi dengan cara mengatupkan seluruh daun keatas dengan tangan sampai tegak lurus kemudian dilakukan pengukuran secara vertikal pada bagian tanaman yang paling tinggi dari permukaan tanah. Tanah tanaman diukur setiap 1 minggu sekali Berdasarkan bahwa rataan tinggi rumput $(\mathrm{cm})$ tertinggi pada pemotongan I terdapat pada perlakuan P2 yaitu sebesar $63,00 \mathrm{~cm}$ dan yang terendah pada 
perlakuan P1 yaitu sebesar 53,20 cm. Hasil analisis ragam pada pemotongan I menunjukkan hasil yang berbeda nyata $(\mathrm{P}<0,05)$. Hasil uji lanjut pada pemotongan I menunjukkan hasil perlakuan P0 tidak berbeda nyata dengan P1, P2 dan P3 akan tetapi P1 menunjukkan hasil yang berbeda nyata dengan P2. Data rataan tinggi rumput $(\mathrm{cm})$ tertinggi pada pemotongan II terdapat pada P3 sebesar 103,20 cm dan yang terendah adalah P1 yaitu 61,60 cm.

Tabel 1. Rekapitulasi hasil penelitian pengaruh tingkat fungi Mikoriza arbuskular terhadap produktivitas rumput gajah mini (Pennisetum purpureum schamach)

\begin{tabular}{|c|c|c|c|c|}
\hline \multirow[b]{2}{*}{ Perlakuan } & \multicolumn{4}{|c|}{ Parameter penelitian } \\
\hline & $\begin{array}{c}\text { Tinggi } \\
\text { tanaman }(\mathrm{cm})\end{array}$ & $\begin{array}{c}\text { Jumlah anakan } \\
\text { (rumpun) }\end{array}$ & $\begin{array}{c}\text { Produksi bahan } \\
\text { kering }(\mathrm{g})\end{array}$ & $\begin{array}{c}\text { Biomassa akar } \\
(\mathrm{g})\end{array}$ \\
\hline \multicolumn{5}{|l|}{ Pemotongan I } \\
\hline $\mathrm{P} 0$ & $58.20^{\mathrm{ab}}$ & $1.80^{\mathrm{b}}$ & $25.75^{\mathrm{tn}}$ & $46.95^{\mathrm{b}}$ \\
\hline $\mathrm{P} 1$ & $53.20^{\mathrm{b}}$ & $3.40^{\mathrm{ab}}$ & $30.32^{\mathrm{tn}}$ & $54.45^{\mathrm{b}}$ \\
\hline $\mathrm{P} 2$ & $63.00^{\mathrm{a}}$ & $4.00^{\mathrm{ab}}$ & $27.76^{\mathrm{tn}}$ & $53.78^{b}$ \\
\hline P3 & $54.60^{\mathrm{b}}$ & $5.80^{\mathrm{a}}$ & $20.66^{\mathrm{tn}}$ & $111.33^{\mathrm{a}}$ \\
\hline \multicolumn{5}{|l|}{ Pemotongan II } \\
\hline $\mathrm{P} 0$ & $80.40^{\mathrm{ab}}$ & $4.80^{b}$ & $24.20^{\mathrm{tn}}$ & \\
\hline $\mathrm{P} 1$ & $61.60^{\mathrm{b}}$ & $5.60^{\mathrm{b}}$ & $24.11^{\mathrm{tn}}$ & \\
\hline $\mathrm{P} 2$ & $81.60^{\mathrm{ab}}$ & $10.40^{\mathrm{a}}$ & $23.99^{\mathrm{tn}}$ & \\
\hline P3 & $103.20^{\mathrm{a}}$ & $10.40^{\mathrm{a}}$ & $25.80^{\mathrm{tn}}$ & \\
\hline \multicolumn{5}{|l|}{ Pemotongan III } \\
\hline $\mathrm{P} 0$ & $127.40^{\operatorname{tn}}$ & $6.80^{b}$ & $18.55^{\mathrm{b}}$ & \\
\hline $\mathrm{P} 1$ & $105.60^{\mathrm{tn}}$ & $7.80^{\mathrm{b}}$ & $17.30^{\mathrm{b}}$ & \\
\hline $\mathrm{P} 2$ & $116.20^{\mathrm{tn}}$ & $12.60^{\mathrm{a}}$ & $25.22^{\mathrm{a}}$ & \\
\hline P3 & $135.00^{\mathrm{tn}}$ & $12.60^{\mathrm{a}}$ & $20.91^{\mathrm{ab}}$ & \\
\hline
\end{tabular}

Hasil analisis ragam pada pemotongan II menunjukkan hasil yang berbeda nyata $(\mathrm{P}<0,05)$. Hasil uji lanjut menunjukkan bahwa $\mathrm{P} 0$ tidak berbeda nyata dengan $\mathrm{P} 1, \mathrm{P} 2$ dan $\mathrm{P} 3$ akan tetapi P1 berbeda nyata dengan P3. Pada pemotongan III, rataan tinggi rumput yang tertinggi yaitu pada P3 $(135,00 \mathrm{~cm})$ dan terendah pada P1 $(105,60 \mathrm{~cm})$.

Hasil analisis ragam pada pemotongan III menunjukkan perbedaan yang tidak nyata $(\mathrm{P}>0,05)$ artinya pemberian mikoriza yang sedikit mampu meningkatkan tinggi tanaman. Hal ini dikarenakan pemanfaatan mikoriza lebih tampak pada akar dalam penyerapan unsur hara. Hal ini sesuai dengan pernyataan Rungkat (2009), yang menyatakan bahwa Tanaman yang bermikoriza biasanya tumbuh lebih baik dari pada tanaman yang tidak bermikoriza. Mikoriza memiliki 
peranan bagi pertumbuhan dan produksi tanaman, peranan mikoriza bagi tanaman sebagai berikut: a) mikoriza meningkatkan penyerapan unsur hara, b) mikoriza melindungi tanaman inang dari pengaruh yang merusak yang disebabkan oleh stres kekeringan, c) mikoriza dapat beradaptasi dengan cepat pada tanah yang terkontaminasi, d) mikoriza dapat melindungi tanaman dari patogen akar e) mikoriza dapat memperbaiki produktivitas tanah dan tanah memantapkan struktur tanah.

Perlakuan P3 menunjukkan hasil terbaik pada tinggi rumput gajah mini pemotongan II yaitu dengan rataan sebesar 103,20 $\mathrm{cm}$. Pemberian mikoriza memberikan hasil yang positif pada pertumbuhan rumput gajah, khususnya pada tinggi tanaman. Hal ini sesuai dengan pernyataan Hardjowigeno (1993), yang menyatakan bahwa pengaruh mikoriza terhadap pertumbuhan secara umum dinyatakan bahwa tanaman yang bermikoriza tumbuh lebih baik dari tanaman tanpa mikoriza. Penyebab utama adalah mikoriza secara efektif dapat meningkatkan unsur hara, baik unsur hara makro maupun mikro. Selain dari pada itu akar yang bermikoriza dapat menyerap unsur hara dalam bentuk terikat dan tidak tersedia bagi tanaman. Cuaca dan lingkungan sangat berpengaruh pada pertumbuhan rumput gajah mini. Penelitian ini dilakukan pada musim hujan (November - Februari), sehingga menyebabkan beberapa polybag tergenang oleh air hujan hingga menyebabkan perkembangbiakan mikoriza terhambat atau bahkan tidak berkembang sama sekali. Hal ini sesuai dengan pernyataan Smith dan Read (1997), yang menyatakan bahwa mikoriza adalah suatu struktur khas pada sistem perakaran yang terbentuk sebagai manifestasi adanya simbiosis mutualis antara fungi (myces) dan perakaran (rhiza) dari tumbuhan tingkat tinggi. Berdasarkan struktur dan cara infeksinya pada sistem perakaran inang maka mikoriza dapat dikelompokkan ke dalam dua golongan besar yaitu ektomikoriza dan endomikoriza.

Hasil penelitian diuji dengan uji jarak berganda duncan menunjukkan pengaruh yang nyata $(\mathrm{P}<0,01)$ terhadap rataan tinggi rumput. Hasil uji lanjut menunjukkan bahwa pada pemotongan I, P3 (mikoriza $30 \mathrm{~g}$ ) tidak berbeda nyata dengan P1 (mikoriza $10 \mathrm{~g}$ ) dan P0 (tanpa mikoriza). Sementara itu P2 (mikoriza $20 \mathrm{~g}$ ) tidak berbeda nyata dengan P0 (tanpa mikoriza). Pemotongan II menunjukkan P3 tidak berbeda nyata dengan P0 dan P2. Sementara itu P1 tidak berbeda nyata dengan P0 dan P2.

Hubungan antara level pemberian mikoriza arbuskula terhadap tinggi tanaman rumput Gajah Mini dapat dilihat pada Gambar 1. 


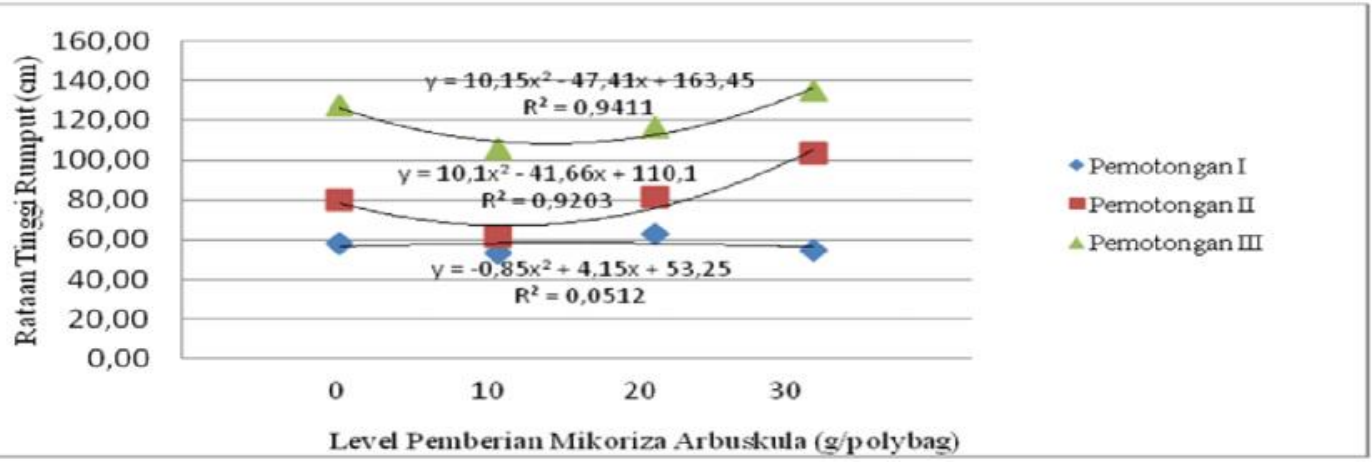

Gambar 1. Diagram Hubungan antara level pemberian mikoriza arbuskula terhadap tinggi rumput Gajah Mini

Grafik di atas menunjukkan bahwa level pemberian mikoriza arbuskula sebanyak 30 g/polybag pada pemotongan II dan III memberikan hasil yang terbaik pada tinggi rumput. Hardjowigeno (1993), menyatakan bahwa pengaruh mikoriza terhadap pertumbuhan secara umum dinyatakan bahwa tanaman yang bermikoriza tumbuh lebih baik dari tanaman tanpa mikoriza. Penyebab utama adalah mikoriza secara efektif dapat meningkatkan unsur hara, baik unsur hara makro maupun mikro. Selain dari pada itu akar yang bermikoriza dapat menyerap unsur hara dalam bentuk terikat dan tidak tersedia bagi tanaman.

\section{Jumlah Anakan (rumpun)}

Anakan rumput yang dihitung adalah anakan yang muncul dari dalam tanah atau tumbuh pada rhizoma batang sesuai perlakuan. Jumlah anakan diukur setiap satu minggu sekali.

Berdasarkan hasil penelitian pada pemotongan I yang tertinggi yaitu pada P3 (5,80 rumpun) dan terendah terdapat pada P0 (1,80 rumpun) sedangkan pada pemotongan II yang tertinggi yaitu P2 dan P3 (10,40 rumpun) dan yang terendah pada P0 (4,80 rumpun). Pemotongan III menunjukan hasil tertinggi pada P2 dan P3 (12,60 rumpun) dan terendah pada P0 (6,80 Rumpun).

Hasil analisis ragam pada pemotongan I, II dan III menunjukkan hasil yang berbeda nyata $(\mathrm{P}<0,05)$. Hasil uji lanjut menunjukkan bahwa pemotongan I pada P0 tidak berbeda nyata dengan P1 dan P2 akan tetapi berbeda nyata dengan P3, begitu juga dengan P1 tidak berbeda nyata dengan P2 dan P3. Pemotongan II menunjukkan P0 tidak berbeda nyata dengan P1 tetapi berbeda nyata dengan P2 dan P3. Pemotongan III menunjukkan bahwa P0 tidak berbeda nyata dengan P1 tetapi berbeda nyata dengan P2 dan P3. Hasil rataan jumlah anakan menunjukan hasil 
yang berbeda nyata pada setiap pemotongan dikarenakan pemanfaatan mikoriza lebih tampak pada akar dalam penyerapan unsur hara. Hal ini sesuai dengan pernyataan Setiadi (1998) dalam Wicaksono dan Ricky (2010), yang menyatakan bahwa mikoriza memberikan manfaat bagi tanaman diantaranya adalah: 1) meningkatkan serapan unsur hara, 2) meningkatkan ketahanan terhadap kekeringan, 3) kerusakan jaringan korteks akibat kekeringan pada perakaran bermikoriza tidak bersifat permanen, 4) memperluas penyebaran hifa dalam tanah sehingga dapat mengambil air relatif lebih banyak, serta 5) memproduksi hormon dan zat pengatur tumbuh seperti auxin, sitokinin, giberelin dan vitamin bagi inangnya. Level mikoriza $0 \mathrm{~g}, 5 \mathrm{~g}$ dan $10 \mathrm{~g}$ menunjukkan bahwa penggunaan mikoriza level $10 \mathrm{~g}$ memberikan hasil terbaik pada tanaman kentang (Solanum tuberosum L.), yang ditandai dengan tingkat kandungan protein tertinggi dan karbohidrat 22,48

Dosis mikoriza dan $30 \mathrm{~g}$ memberikan pengaruh yang terbaik terhadap pertumbuhan rumput gajah meskipun tanah yang digunakan disini adalah tanah jenis ultisol, yaitu tanah yang kandungan unsur haranya rendah (tanah masam). Karena salah satu manfaat fungi mikoriza arbuskula adalah dapat menghasilkan hormon pertumbuhan pada inangnya, sehingga tanaman bermikoriza dapat tumbuh lebih baik daripada yang tidak bermikoriza. Hal ini sesuai dengan pernyataan Setiadi (1998), yang menyatakan bahwa mikoriza memberikan manfaat bagi tanaman diantaranya adalah: meningkatkan serapan unsur hara, meningkatkan ketahanan terhadap kekeringan dan memproduksi hormon dan zat pengatur tumbuh seperti auxin, sitokinin, giberelin dan vitamin bagi inangnya.

Fungi Mikoriza arbuskula (FMA) dapat bertahan hidup dan bereaksi pada kondisi tanah masam (rendah unsur hara). Hal ini sesuai dengan pernyataan Fitter dan Hay (1991), yang menyatakan bahwa mikoriza mempunyai peranan yang besar dalam pengelolaan tanah mineral masam tropika. Pada tanah-tanah tersebut ditemukan beberapa spesies mikoriza yang mempunyai ketahanan tinggi terhadap kemasaman dan keracunan Al serta berpotensi besar dalam meningkatkan pertumbuhan dan produksi tanaman.

Perlakuan dosis mikoriza $20 \mathrm{~g}$ dan $30 \mathrm{~g}$ memberikan hasil rataan jumlah anakan tertinggi pada rumput gajah pemotongan III yaitu sebesar 12,60 rumpun dan yang terendah terdapat pada kontrol (P0) atau tanpa perlakuan yaitu sebesar 6,80 rumpun. Ini menunjukkan bahwa rumput gajah mini dapat tumbuh di segala macam kondisi tanah, meskipun hasil pertumbuhannya tidak sama. Rumput gajah mini dikenal sebagai tanaman yang dapat beradaptasi dengan kondisi 
lingkungan yang cukup ekstrim. Hal ini sesuai dengan pernyataan Sumarsono (2005), yang menyatakan bahwa rumput gajah mini dapat ditanam pada lingkungan hawa panas yang lembab, tetapi tahan terhadap musim panas yang cukup tinggi dan dapat tumbuh dalam keadaan yang tidak seberapa dingin. Rumput ini juga dapat tumbuh dan beradaptasi pada berbagai macam tanah meskipun hasilnya akan berbeda. Perkembang biakan vegetatif dilakukan baik dengan cara membagi rumpun akar dan bonggol maupun dengan stek batang (minimal 3 ruas, 2 ruas terbenam di tanah).

Hasil analisis keragaman jumlah anakan sehingga dilanjutkan dengan Uji Jarak Berganda Duncan. Pemotongan I menunjukkan bahwa P3 tidak berbeda nyata dengan P1 dan P2. Sementara itu P0 tidak berbeda nyata dengan P2 dan P3, akan tetapi P0 berbeda nyata dengan P3. Pemotongan II menunjukkan P0 tidak berbeda nyata dengan P1, sementara itu P2 tidak berbeda nyata dengan P3 akan tetapi berbeda nyata dengan P0 dan P1. Pemotongan III menunjukkan bahwa P0 tidak berbeda nyata dengan P1 sedangkan P2 tidak berbeda nyata dengan P3. Akan tetapi P0 dan P1 berbeda nyata dengan P2 dan P3.

Hubungan antara level pemberian mikoriza arbuskula terhadap jumlah anakan rumput Gajah Mini dapat dilihat pada Gambar 2.

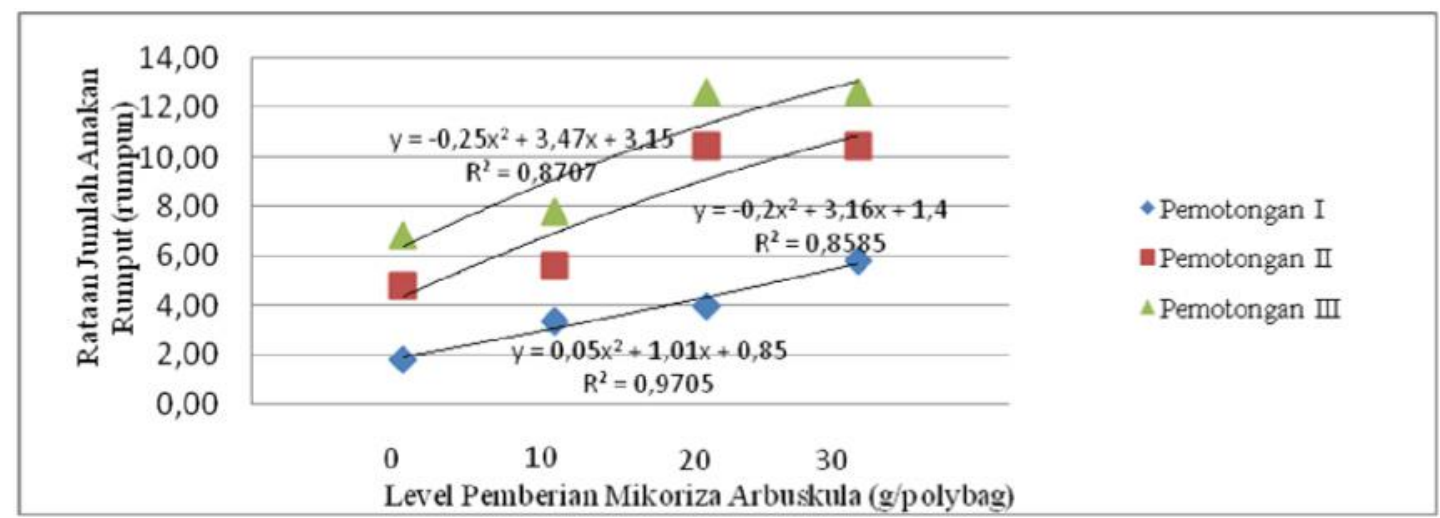

Gambar 2. Hubungan antara level pemberian mikoriza arbuskula terhadap jumlah anakan rumput Gajah Mini

Dari grafik di atas dapat kita lihat bahwa pertumbuhan jumlah anakan rumput gajah mini pada ketiga pemotongan selalu mengalami peningkatan. Jumlah anakan terbanyak diperoleh pada rumput yang diberikan mikoriza sebanyak 30 g/polybag. Hardjowigeno (1993), menyatakan bahwa pengaruh mikoriza terhadap pertumbuhan secara umum dinyatakan bahwa tanaman yang bermikoriza tumbuh lebih baik dari tanaman tanpa mikoriza. Penyebab utama adalah mikoriza secara efektif dapat meningkatkan unsur hara, baik unsur hara makro maupun 
mikro. Selain dari pada itu akar yang bermikoriza dapat menyerap unsur hara dalam bentuk terikat dan tidak tersedia bagi tanaman.

Susetyo (1980), mengatakan bahwa pemotongan mempunyai pengaruh yang sangat besar terhadap produksi bahan segar, bahan kering, jumlah anakan, nilai gizi, daya cerna maupun tingkat konsumsi oleh ternak. Hal yang sama juga dikemukakan oleh Nasution (1991) bahwa produksi segar hijauan terus mengalami peningkatan seiiring dengan meningkatnya interval pemotongan.

\section{Produksi Bahan Kering (g)}

Produksi bahan kering diperoleh dari produksi bahan segar dari setiap pemotongan umur 4 minggu, setelah pemotongan dilakukan penimbangan tiap petak percobaan.

Perlakuan P1 pada pemotongan I memiliki rataan produksi bahan kering cenderung tinggi dibandingkan perlakuan lainnya, yaitu sebesar 30,32 g dan kecenderungan yang terendah terdapat pada P3 yaitu 20,66 g. Hasil analisis ragam produksi bahan kering rumput pada pemotongan I menunjukkan hasil yang tidak berbeda nyata $(\mathrm{P}>0,05)$. Hal ini dikarenakan adanya beda volume air pada waktu penyiraman, sehingga penerimaan akar terhadap air tidak seimbang mengakibatkan adanya perbedaan produksi bahan kering pada rumput. Fitter dan Hay (1991), menyatakan bahwa pada tahap pertumbuhan vegetatif, air digunakan oleh tanar melangsungkan proses pembelahan dan pembesaran sel yang terlihat dari pertambal. tanaman, diameter, perbanyakan daun dan petumbuhan akar. Cekaman air menyebabkan penurunan turgor pada sel tanaman dan berakibat pada penurunan proses fisiologi yang mempengaruhi produktivitas rumput termasuk produksi bahan kering rumput.

Produksi bahan kering rumput gajah mini pada pemotongan II cenderung tinggi terdapat pada perlakuan P3 yaitu dengan rataan sebesar 25,80 g dan yang rendah kecendrungan terdapat pada P2 yaitu sebesar 23,99 g. Hasil analisis keragaman produksi bahan kering rumput gajah pada pemotongan II, hasilnya adalah berbeda tidak nyata $(\mathrm{P}>0,05)$.

Berdasarkan hasil penelitian dapat dilihat bahwa perlakuan P2 merupakan perlakuan dengan produksi bahan kering tertinggi yaitu sebesar 25,22 $\mathrm{g}$ dan yang terendah adalah perlakuan P1 yaitu sebesar 17,30 g. Analisis ragam produksi bahan kering rumput gajah pada pemotongan III adalah berbeda nyata $(\mathrm{P}<0,05)$. Hasil uji lanjut menunjukkan bahwa pada pemotongan III terhadap produksi bahan kering yaitu P0 tidak berbeda nyata dengan P1 dan P3 
akan tetapi berbeda nyata dengan P2. Perlakuan P2 berbeda nyata dengan P0 dan P1, tetapi tidak berbeda nyata dengan P3. Kandungan bahan kering pada tiap interval pemotongan terus mengalami perbahan untuk setiap perlakuan. Karena salah satu faktor yang berpengaruh terhadap bahan kering hijauan adalah interval pemotongan (trimming) yang dilakukan. Hal ini sesuai dengan pernyataan Chowder dan Cheda (1982), yang menyatakan bahwa interval pemotongan berpengaruh terhadap produksi hijauan, nilai nutrisi, kemampuan untuk tumbuh kembali, komposisi botani dan ketahanan spesies. Ferkuensi pemotongan berlaku, bahwa pada batas tertentu frekuensi yang semakin rendah akan mengakibatkan produksi kumulatif bahan kering semakin tinggi dibandingkan produksi kumulatif oleh pemotongan yang lebih sering.

Hubungan antara level pemberian mikoriza arbuskula terhadap produksi bahan kering rumput Gajah Mini dapat dilihat pada Gambar 4.

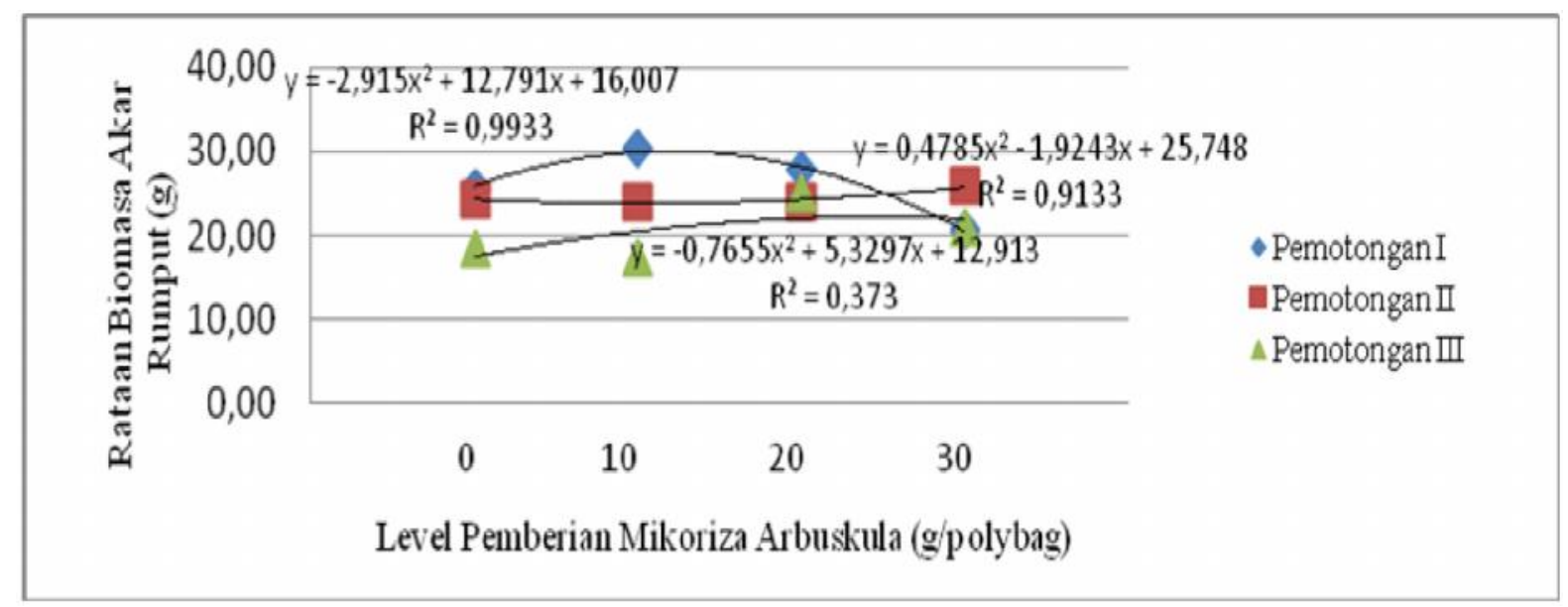

Gambar 3. Hubungan antara level pemberian mikoriza arbuskula terhadap produksi bahan kering rumput Gajah Mini

Grafik di atas menunjukkan bahwa produksi bahan kering rumput gajah mini mengalami peningkatan pada pemotongan II dan III. Produksi bahan kering tertinggi diperoleh pada pemberian mikoriza arbuskula sebanyak 30 g/polybag. Fitter dan Hay (1991), menyatakan bahwa pengaruh mikoriza terhadap pertumbuhan secara umum dinyatakan bahwa tanaman yang bermikoriza tumbuh lebih baik dari tanaman tanpa mikoriza. Penyebab utama adalah mikoriza secara efektif dapat meningkatkan unsur hara, baik unsur hara makro maupun mikro. Selain dari pada itu akar yang bermikoriza dapat menyerap unsur hara dalam bentuk terikat dan tidak tersedia bagi tanaman. 


\section{Biomasa Akar (g)}

Biomassa akar diperoleh dengan menimbang berat segar akar setelah pemotongan terakhir (ketiga) dan juga menimbang produksi kering akar setelah oven.

Rataan biomasa akar rumput gajah tertinggi terdapat pada perlakuan P3 yaitu sebesar 111,33 g dan yang terendah terdapat pada perlakuan P0 yaitu sebesar 46,95 g. Semakin banyak dosis mikoriza yang diberikan pada tanaman, maka kan semakin besar pula bintil akar yang dihasilkan oleh tanaman inangnya tersebut. Ini disebabkan karena fungi mikoriza arbuskula bekerja pada akar inangnya seperti jaringan hifa yang semakin banyak. Hal ini sesuai dengan pernyataan Setiadi (1998), yang menyatakan bahwa mikoriza memberikan manfaat bagi tanaman diantaranya adalah: 1) meningkatkan serapan unsur hara, 2) meningkatkan ketahanan terhadap kekeringan, 3) kerusakan jaringan korteks akibat kekeringan pada perakaran bermikoriza tidak bersifat permanen, 4) memperluas penyebaran hifa dalam tanah sehingga dapat mengambil air relatif lebih banyak, serta 5) memproduksi hormon dan zat pengatur tumbuh seperti auxin, sitokinin, giberelin dan vitamin bagi inangnya.

Hubungan antara level pemberian mikoriza arbuskula terhadap biomasa akar rumput Gajah Mini dapat dilihat pada Gambar 4.

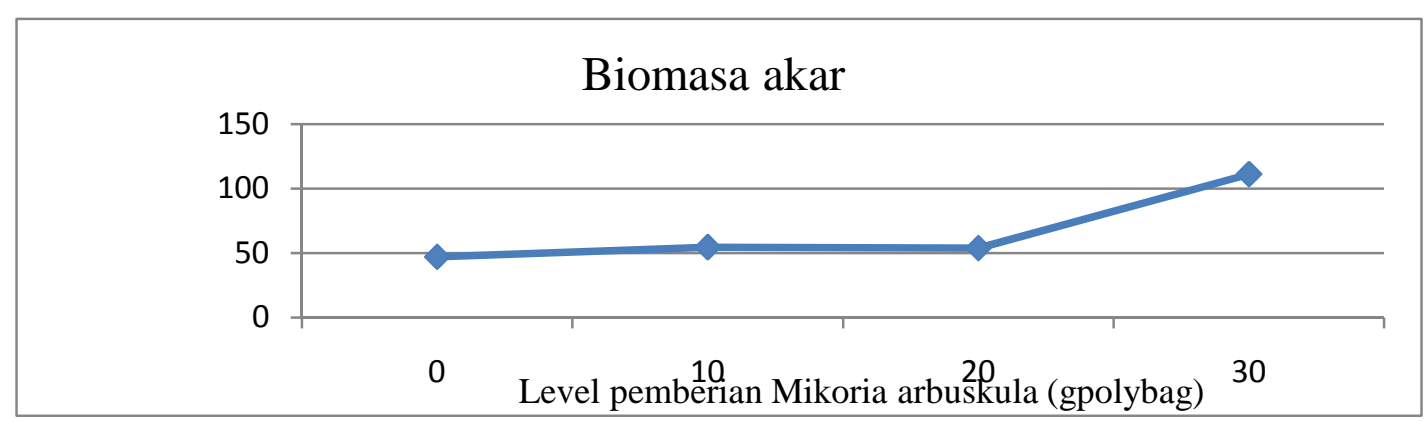


Wicaksono dan Ricky (2010), menyatakan bahwa penggunaan mikoriza level 10g memberikan hasil terbaik pada tanaman kentang (Solanum tuberosum L.), yang ditandai dengan tingkat kandungan protein tertinggi dan karbohidrat 22,48\%.

\section{KESIMPULAN}

Pemberian Fungi Mikoriza Arbuskula (FMA) dapat meningkatkan produktivitas rumput gajah mini (Pennisetum purpureum schamach). Level mikoriza arbuskula $30 \mathrm{~g} / \mathrm{polybag}$ menunjukkan hasil yang paling baik terhadap respon tinggi tanaman, jumlah anakan, produksi bahan segar dan biomasa akar rumput gajah mini (Pennisetum purpureum schamach).

\section{DAFTAR PUSTAKA}

Aryanto dan D. Polakitan, 2009. Uji produksi rumput dwarf (Pennisetum purpureum CV. Dwarf). Jurnal Ilmiah, Balai Pengkajian Teknologi Pertanian Sulawesi Utara, JL. Kampus Pertanian Kalasey.

Crowder, L. V. Dan H.R. Cheda, 1982. Tropical Grassland Husbandry. Longman, London.

Fitter A.H., Hay R.K.M. 1991. Fisiologi Lingkungan Tanaman. Gadjah Mada University Press. Yogyakarta.

Hardjowigeno, S., 1993. Ilmu Tanah. Mediyatama Sarana Perkasa, Jakarta.

Nasution, H.F., 1991. Pengaruh Interval dan Tinggi Pemotongan Terhadap Produksi Rumput Setaria. Fakultas Pertanian Universitas SumateraUtara, Medan.

Reksohadiprodjo, S. 1985. Produksi Tanaman Hijauan Makanan Ternak Tropika. BPFE, Yogyakarta.

Rismunandar. 1986. Mendayagunakan Tanaman Rumput. Sinar Baru, Bandung

Rungkat, J. A., 2009. Peranan MVA dalam Meningkatkan Pertumbuhan dan Produksi Tanaman. Jurnal Formas 2 (4): 270 - 276.

Setiadi, Y., 1998. Pemanfaatan Mikroorganisme dalam Kehutanan. Departemen Pendidikan dan Kebudayaan. Dirjen Pendidikan Tinggi, Bioteknologi Pusat Antar Universitas. IPB, Bogor.

Smith, S. E. dan D. J. Read. 1997. Mycorrhizal Symbiosis. Academic Press, UK. 
Sumarsono, 2005. Pertanian Organik. Cetakan Pertama. Badan Penerbit Universitas Diponegoro, Semarang.

Susetyo, S. 1980. Padang Penggembalaan dan Pengelolaan Pastura dan Padang Rumput. FP IPB, Bogor. 
Jurna 